\title{
Antoine Lavalette, Slave Murderer: A Forgotten Scandal of the French West Indies
}

\author{
Andrew Dial \\ Georgetown University, Washington, DC, USA \\ andrew.dial@mail.mcgill.ca
}

\begin{abstract}
The name Antoine Lavalette $(1708-67)$ is infamous within the Society of Jesus. The superior of the Martinique mission in the mid-eighteenth century, he is known for triggering the 1764 expulsion from France. Less known is his torture to death of four enslaved men and women. The visitor sent to investigate Lavalette's commercial activities, Jean-François de la Marche (1700-62), discovered these murders and reported them to Rome. This paper analyzes La Marche's account of the atrocities within their Caribbean context. It demonstrates that Lavalette's killings were within the established norms of the planter class. It further argues that his actions were part of the Society's attempts to reconcile its religious calling with the gruesome realities of plantation slavery.
\end{abstract}

\section{Keywords}

slavery - Antoine Lavalette - Martinique - scandal - Caribbean - sorcery - expulsion torture - murder

The name Antoine Lavalette is infamous. The story of his financial legerdemain triggering the expulsion from France is well known. As the superior of the mission on the Caribbean island of Martinique from 1753 through 1762, Lavalette tried to increase the mission's revenue through a transatlantic system of currency arbitrage but ran up significant debts instead. When he was unable to honor these debts, his creditors in France sued the Society as a whole for restitution. The cases reached France's highest court, the parlement of Paris, where they became a public scandal (the "Lavalette affair") and provoked 
the Jesuits' enemies, the Jansenists, to call for further investigations into the Society's Constitutions. Meanwhile, a visitor dispatched from France, JeanFrançois de la Marche, investigated Lavalette and removed him from power. This is the story, consisting of financial impropriety and public scandal, which has been preserved in the Society's collective memory. ${ }^{1}$

A close look at La Marche's report to the Jesuit curia in Rome, however, reveals another, darker scandal. La Marche did not begin by addressing Lavalette's financial affairs. Instead, he accused Lavalette of torturing to death four of the mission's enslaved men and women: Catherine, Martin, Renata, and Condo. This constituted an act of voluntary homicide, a horrified La Marche concluded, beyond the powers of a visitor to absolve. ${ }^{2}$ Lavalette was a murderer.

This article explores Lavalette's killings through La Marche's report, our only source of knowledge about them. ${ }^{3}$ Examining this atrocity not only redefines our understanding of Lavalette, which has previously been limited to his financial activities, ${ }^{4}$ but it underscores the paradox of a slaveholding Society of Jesus. Historians of slavery have described the plantation as being founded on fear:

1 See the treatment in Camille Rochemonteix, Le père Antoine Lavalette à la Martinique: D'après beaucoup de documents inédits (Paris: A. Picard, 1907); Dale K. Van Kley, The Jansenists and the Expulsion of the Jesuits from France, 1757-1765 (New Haven: Yale University Press, 1975), 90-136; D. G. Thompson, "The Lavalette Affair and the Jesuit Superiors," French History 10, no. 2 (June 1, 1996): 206-39; Frederik Vermote, "Financing Jesuit Missions," in The Oxford Handbook of the Jesuits, ed. Ines G. Županov (New York: Oxford University Press, 2019), 128-52; Marc Fumaroli, "Between the Rigorist Hammer and the Deist Anvil: The Fate of the Jesuits in EighteenthCentury France," in The Jesuits II: Cultures, Sciences and the Arts, ed. John W. O'Malley et al. (Toronto: University of Toronto Press, 2006), 685-86.

2 La Marche sent six reports to Rome during his Caribbean investigations. The report that mentions the slave killings, of March 18, 1762 from Dominica, is by far the longest and most complete. It consists of eleven findings, of which only the first mentions slavery and the slave tortures. The rest summarize his investigation into Lavalette's financial affairs. It is this document that I refer to as his "report." "Condo" may not have been the enslaved person's name. It is always underlined in La Marche's letter, where the other names are not. Ricci's reference to the atrocity (see below) refers to three people being killed. La Marche to Ricci, March 18, 1762, Archivum Romanum Societatis Iesu [hereafter ARSI], Gall. 114 I, fols. $67^{\mathrm{r}}-73^{\mathrm{v}}$. The slave killings are described in fols. $67^{\mathrm{v}}-68^{\mathrm{r}}$. Henceforth cited as La Marche, "Report."

3 Lavalette's killings do appear one other time in the ARSI files outside La Marche's report. Superior General Lorenzo Ricci (1703-75, in office 1758-73) refers to La Marche's report in his history of the Society's expulsion from France, but this is merely a passing reference to La Marche's report and does not include any different information. See Thompson, "Lavalette Affair and the Jesuit Superiors," 215.

4 Camille de Rochemonteix, who read La Marche's report, ignored the murders entirely while D. G. Thompson, who does not appear to have read it, states that Lavalette was "rumored" to have tortured slaves to death. Rochemonteix, Antoine Lavalette, 154-56; Thompson, "Lavalette Affair and the Jesuit Superiors," 215. 
fear of revolt, fear of poisonings, fear of the black "other." This fear-based world ran counter to Ignatius's vision of a Society built on faith and love. The Society was among the most successful slaveholders in the Americas, with over twenty thousand people in their possession at the mid-eighteenth-century expulsions. The paradox of a religious order built on Christian love yet supported by the exploitation of human beings surfaced again and again as provincials and superiors general responded to reports of cruelty on the Society's plantations. La Marche's report, with its tone of shock and horror, was one such moment where the paradox of a slaveholding Society crystalized.

\section{Jesuit Slaveholding}

The Society's ownership of human beings was controversial from its first acquisition of enslaved Africans in Angola and Brazil in the sixteenth century. Several superiors general commanded the Portuguese province to desist but priests in the colonies ignored them. The ubiquity of slavery in the colonies, they argued, and the lack of an alternative labor source required the ownership of enslaved Africans. By 1600, Rome gave up issuing remonstrances, making the slaveholding Society a fait accompli. ${ }^{5}$ A parallel process of negotiation led to the first Jesuit hacienda in Mexico (Santa Lucía, 1567) and sugar plantation in Brazil (Mamo, 1601). ${ }^{6}$ The order implicated itself further with Atlantic slavery during the seventeenth century. Jesuit theologians Luis de Molina (1535160o) and Francisco Suárez (1548-1617) penned justifications of slavery, ${ }^{7}$ while those who questioned the practice were either reassigned or, in the case of Alonso de Sandoval (1576-1652), discouraged in their investigations. ${ }^{8}$ During

5 Dauril Alden, The Making of an Enterprise: The Society of Jesus in Portugal, Its Empire, and beyond, 1540-1750 (Stanford, CA: Stanford University Press, 1996), 506-9; William V. Bangert, A History of the Society of Jesus (St. Louis, MO: Institute of Jesuit Sources, 1972), 163.

6 For the haciendas, see Herman W. Konrad, A Jesuit Hacienda in Colonial Mexico: Santa Lucía, 1576-1767 (Stanford, CA: Stanford University Press, 1980), 20-38. For the sugar plantations, see Alden, Enterprise, 416; Alden, "Sugar Planters by Necessity, Not Choice: The Role of the Jesuits in the Cane Sugar Industry of Colonial Brazil, 1601-1759," in The Church and Society in Latin America: Selected Papers from the Conference at Tulane University, New Orleans, Louisiana, April 29-30, 1982, ed. Jeffrey A. Cole (New Orleans, LA: Center for Latin American Studies, Tulane University, 1984), 144.

7 Robin Blackburn, The Making of New World Slavery: From the Baroque to the Modern, 1492-180o (London: Verso, 1997), 179-80; Alden, Enterprise, 510-11 and 526.

8 See these examples in Carlos Alberto Zeron, "Les jésuites et le commerce d'esclavage entre le Brésil et l'Angola à la fin du XVIe siècle," in Brésil, Quatre siècles d'esclavage: Nouvelles questions, nouvelles recherches (Paris: Karthala and CIRESC, 2012), 67-84. 
TABLE 3.1 Enslaved people owned by the Society of Jesus c.176o

Province $\quad$ Enslaved People

$\begin{array}{ll}\text { Brazil } & 5,686 \\ \text { Peru } & 5,224 \\ \text { Paraguay } & 3,164 \\ \text { France } & \text { At least 1,816 (see Table 2) } \\ \text { Quito } & 1,364 \\ \text { Chile } & 1,121 \\ \text { Goa (Mozambique prezos only) } & 810 \\ \text { Maranhão } & 736 \\ \text { Mexico (Cuba only) } & 406 \\ \text { New Grenada } & 358 \\ \text { England (Maryland farms) } & 192 \\ \text { Total } & \text { at least 2o,877 }\end{array}$

Note: These numbers are based on preliminary research are not exhaustive.

SOURCES: Alden, Enterprise, 524; William Francis Rea, The Economics of the Zambezi Missions (Rome: Institutum Historicum Societatis Iesu, 1976), 129; Mercedes García Rodríguez, Misticismo y capitales: La Compañía de Jesús en la economía habanera del siglo xviii (Havana: Editorial de ciencias sociales, 2000), 67-69; and Thomas Murphy, Jesuit Slaveholding in Maryland, 17171838 (New York: Routledge, 2001), 45-47.

the mid-eighteenth-century suppressions, inventories of the Jesuits' properties showed that the Society owned over twenty thousand people (Table 1), double the number of ordained Jesuit priests. ${ }^{9}$

At least eighteen hundred slaves worked on Jesuit plantations in the French Caribbean, with the Martinique mission owning several hundred enslaved men and women (Table 2). As in the Iberian empires, the Jesuits became slaveholders upon arrival. The first priests to install themselves in 1640 established a residence and plantation complex on a hill overlooking St. Pierre, Martinique's commercial hub. ${ }^{10}$ A 1660 census listed a sugar mill and forty-five enslaved Africans attached to the Jesuits, making them one of the island's first sugar

9 See the figures in Andrew Dial, “The 'Lavalette Affair': Jesuits and Money in the French Atlantic" (PhD diss., McGill University, 2018), 48. For the number of priests, see Louis Denis, Atlas géographique renfermant les établissements des jésuites (Paris: Chez Denis, 1764).

10 Joseph Rennard, Histoire religieuse des Antilles françaises des origines à 1914, d'áprès des documents inédits (Paris: Société de l'histoire des colonies françaises, 1954), 42. 
TABLE 3.2 People enslaved to the Society in the French Americas c.1763

\section{Colony (Plantation) N Number of Enslaved People}

Guiana (Loyola and Mont-Louis

plantations, plus the Oyapoc

mission)

Saint-Domingue (Terre-Rouge and

Port-de-Paix)

Louisiana (New Orleans)

Guadeloupe (Bisdari)

Martinique (St. Pierre)

Dominica (Grand Bay)

Kaskaskia

New France (includes the pays d'en

haut)

Total
Exact figures for 509 , speculation

of around 1,500

380

141

312

At least 200

194

68

Around 12

SOURCES: Guiana: The 509 figure comes from combining the 495 people enumerated on two of the five Jesuit plantations and the fourteen people listed in the missions. Le Roux et al. speculate that the population of all five plantations would have been between one thousand and fifteen hundred. For the Guiana plantations, see Yannick Le Roux et al., Les jésuites et l'esclavage: Loyola - l'habitation des jésuites de Rémire en Guyane française (Québec: Presses de l'Universite du Québec, 2009), 117. For the Guiana missions see Archives Nationales d'Outre Mer [henceforth ANOM] COL Series C14 vol. 36, fol. 250 and vol. 37, fol. 182. Saint Domingue: Archives français de la Société de Jesus (AFSI), F An 41 1/7. Dominica: AFSI Brotier vi fols. $66-72$. For Louisiana: Villiers du Terrage, Les dernières années de la Louisiane française: Le chevalier de Kerlérec d'Abbadie - Aubry Laussant (Paris: Guilmoto, 1904) 162-65. For Martinique and Guadeloupe: Joseph Rennard, Histoire religieuse des Antilles françaises des origins à 1914, d'après des documents inédits (Paris: Société de l'histoire des colonies franćaises, 1954), 248-49. For Kaskaskia: "Some Points on the Jesuit Mission in the Illinois," encl., Gen Thomas Gage to H.S. Conway, June 24, 1766, in Clarence Alvord and Clarence Carter, eds., The New Regime, 1765-1767, Collections of the Illinois State Historical Library, vol. 11 (Springfield, 1916), 326-28. New France: Pierre Trudel, L'esclavage au Canada français: Histoire et conditions de l'esclavage (Québec: Les Presses Universitaires Laval, 196o), 154. Trudel's figures span the first half of the eighteenth century. 
producers and one of the largest slaveholders." ${ }^{11}$ This enslaved population increased to at least 130 people in 1717 and over two hundred people by the 176os. ${ }^{12}$

Observers across the Caribbean portrayed the religious orders as model planters. Religious orders had self-sustaining populations, they claimed, in contrast to secular planters who required a constant influx of new slaves from Africa. One of Martinique's governors, François-Louis de Salignac, Marquis de Fenelon (1722-67), reasoned that this stability stemmed from the priests taking better care of enslaved mothers and children. ${ }^{13}$ Glimpses of the enslaved themselves imply a more macabre reality. The Dominican friar Jean-Baptiste Labat (1663-1738) recorded the death of a woman enslaved to the Jesuits whose sleeve was caught in a sugar mill. Her body was crushed by the machinery. ${ }^{14}$ In 1706, Martinique's superior council convicted Barthélemy, a man enslaved to the Jesuits, of murdering Colin, his wife's lover. The court decided not to punish Barthélemy but sentenced his wife to thirty lashes for adultery and required the Jesuits to pay restitution to Colin's owner. ${ }^{15}$ Death was thus an ever-present reality for the enslaved men and women of the Martinique mission. ${ }^{16}$

The ownership of plantations and enslaved Africans embedded the Society within an exploitative labor system built on fear. Planters in the French Caribbean, like their brethren across the Atlantic's western rim, were surrounded on rural plantations by a sea of enslaved Africans, inducing dread that the enslaved could revolt or poison them at any time. Missionaries were not immune to this fear. "You find yourself alone in a house that is isolated and

11 Jacques Petitjean-Roget and Eugène Bruneau-Latouche, Personnes et familles à la Martinique au XVIIe siècle d'après recensements et terrier nominatifs, vol. 1 (Montreuil: Éditions Desormeau, 2000), 26, 47, and 30. It has been claimed that the Jesuits were the island's largest slaveholders and the first to build a sugar mill but this author finds the evidence to be inconclusive.

12 Antoine d'Arcy de La Varenne to the Conseil de la Marine, Apr. 10, 1717. Archives Nationales d'Outre Mer [henceforth ANOM] COL Series C8A vol. 22, fol. 117. Rennard, Histoire religieuse, 249 .

13 The Marquis de Fénelon on Martinique and Moreau de St. Méry on Saint Domingue are the most commonly cited sources for this view. Gabriel Debien, Les esclaves aux Antilles françaises, XVIIe-XVIIIe siècles (Basse-Terre and Fort-de-France: Société d'histoire de la Guadeloupe and Société d'histoire de la Martinique, 1974), 481; Frantz Tardo-Dino, Le collier de servitude: La condition sanitaire des esclaves aux Antilles françaises du XVIIe au XIXe siècle (Paris: Editions caribéennes: Agence de coopération culturelle et technique, 1985), 167-68. Accidents such as these were common on sugar plantations. Bernard Moitt, Women and Slavery in the French Antilles: 1635-1848 (Bloomington: Indiana University Press, 2001), 5 o.

15 The wife's name was Catherine. Moitt, Women and Slavery, 88.

16 As it was across the Caribbean. See Vincent Brown, The Reaper's Garden: Death and Power in the World of Atlantic Slavery (Cambridge, MA: Harvard University Press, 20o8). 
surrounded by woods and mountains," wrote Jean Baptiste Margat (1689-1747), a Jesuit priest on Saint Domingue, "far from the help you might need at any hour of the day or night, and at the mercy of two Negroes, whose only goal, in some cases, is to do harm to their master."17 This oppressive fear justified the use of violence as a deterrent. Planters described themselves as being at war with their enslaved enemies. They whipped, mutilated, or killed the men and women under their care despite the economic disincentive of damaging their own human property. ${ }^{18}$ Royal officials attempted to limit this violence through legislation but met with limited success. The 1685 Code Noir, which governed the relationship between the owner and the owned in the French Caribbean, placed firm restrictions on the punishments planters could inflict on their slaves. Article 42 permitted owners to chain their slaves and beat them with rods or straps, but not to torture or mutilate their limbs. Article 43 empowered royal officials to criminally prosecute masters who had killed their slaves. Planters ignored these rules with impunity. The Saint Domingue planter Jean-Baptiste Caradeux (1741-1810), nicknamed "the Cruel," buried his enslaved workers alive and let flies eat their exposed heads while he and his assembled guests watched. In 1788, Nicholas Lejeune created a scandal by burning his enslaved men and women with torches. Neither of these planters were punished by royal authorities. French slave law limited the testimony of enslaved men and women in court and required corroboration from free people. On

17 "Une autre épreuve qui peut étonner un nouveau missionnaire accoutumé au tumulte des villes d'Europe et à la vie sociale de nos maisons, c'est la solitude: elle est extrême, lorsque son ministère ne l'appelle point au dehors: ils se trouve seule dans une maison isolée et environné de bois et de montagnes, loin des secours dont on peut avoir besoin à toute heure, livré à la merci de deux Nègres, dont tout l'attention est quelquefois de nuire à leur maitre." Jean Baptiste Margat de Tilly, "Lettre du père Margat, missionnaire de la Compagnie de Jésus, au Procureur-Général des missions de la même Compagnie aux Îles de l’Amérique, Feb. 7, 1725," in Lettres Édifiantes et curieuses, vol. 4 (Lyon: J. Vernarel and Cabin et Cie., 1819), 331-32. I have relied on Chris Rivers's translation of the Margat, Bréban, and Mongin. Where possible, I have placed the untranslated quote in the footnotes. Jean-Baptiste Margat, "Letter from Fr. Margat, Missionary of the Society of Jesus, to Fr.***, of the Same Society (27 February 1725)," "No Less an Object of Our Zeal," French Jesuit Letters on Slavery, https:// jesuitlettersonslavery.wordpress.com/letter-from-fr-margat-missionary-of-the-society-ofjesus-to-fr-of-the-same-society-27-february-1725/ (accessed May 19, 2020).

18 For eloquent descriptions of this dynamic across the Caribbean, see Marisa J. Fuentes, Dispossessed Lives: Enslaved Women, Violence, and the Archive (Philadelphia: University of Pennsylvania Press, 2016); Frédéric Régent, La France et ses esclaves: De la colonisation aux abolitions (1620-1848) (Paris: Bernard Grasset, 2007), 59-89; Trevor G. Burnard, Mastery, Tyranny, and Desire: Thomas Thistlewood and His Slaves in the Anglo-Jamaican World (Chapel Hill: University of North Carolina Press, 2004), 114-42. 
the rare occasions when slaveowners were prosecuted for cruelty, they were acquitted or only fined. ${ }^{19}$

This violence shocked some Jesuit priests who catechized the enslaved population. Claude Bréban (1695-1735), a Jesuit missionary on Saint Domingue, described to his brother in France a vivid list of the atrocities happening around him. One woman, he reported, roasted one of her enslaved people to death over a slow fire while she nonchalantly smoked a pipe. Another thrust a redhot poker into the womb of his enslaved mistress whom he suspected of being unfaithful. "All these bloodthirsty tyrants go about their merry way in the colony without ever facing the slightest objection to their cruelty." Bréban complained, "Doesn't that alone prove the obvious necessity of a Universal Judgment at the end of days?"20 Other missionaries, however, sided with the planter class to lobby for reduced state oversight of punishments. Jesuits in Guiana were among those who protested a 1715 government attempt to ban planters from cutting the ears off of recalcitrant slaves. This resistance implies that they may have been mutilating the bodies of their own enslaved men and women. ${ }^{21}$

The position of Jesuit priests embedded in the violent logic of the plantation drew out a tension within the Society's founding ideals. Ignatius had called for the order to grow through goodness, charity, and a "sincere zeal for souls." 22 However, he also recognized fear's motivating power. The Constitutions called

19 See the examples in Andrew T. Fede, Homicide Justified: The Legality of Killing Slaves in the United States and the Atlantic World (Athens: University of Georgia Press, 2017), 28-32; Sophie White, Voices of the Enslaved: Love, Labor, and Longing in French Louisiana (Chapel Hill: University of North Carolina Press, for the Omohundro Institute of Early American History and Culture, 2019). For Lejeune, see Malick W. Ghachem, "Prosecuting Torture: The Strategic Ethics of Slavery in Pre-Revolutionary Saint-Dominigue (Haiti)," Law and History Review 29, no. 4 (November 2011): 985-1029. For Caradeux, see Paul Burton Cheney, Cul de Sac: Patrimony, Capitalism, and Slavery in French Saint-Domingue (Chicago: University of Chicago Press, 2017), 81.

20 “Tous ces tyrans sanguinnaires vivent heureux dans la colonie, sains qu'on les ait inquiétés tant soit peu sur leur cruauté [...]. Cela seul ne prouve-t-il évidemment la nécessité d'un Jugement universel à la fin des siècles?" Nicholas Dyonet, "Le Père Bréban, missionnaire Berrichon à Saint-Domingue: lettre inédit de janvier 1732," Bulletin du Centre d'Histoire des Espaces Atlantiques 8 (1997): 103-30, here 134; Claude Bréban, "Letter from Fr. Bréban, S.J. (19 January 1732)," "No Less an Object of Our Zeal," French Jesuit Letters on Slavery, https:// jesuitlettersonslavery.wordpress.com/letter-from-fr-breban-s-j-19-january-1732/ (accessed June 2, 2020).

21 Yannick Le Roux, Réginald Auger, and Nathalie Cazelles, Les jésuites et l'esclavage: Loyola, l'habitation des jésuites de Rémire en Guyane française (Québec: Presses de l'Université du Québec, 2009), 12.

22 Ignatius of Loyola, The Constitutions of the Society of Jesus and Their Complementary Norms: A Complete English Translation of the Official Latin Texts, ed. John W. Padberg (Saint Louis, MO: Institute of Jesuit Sources, 1996), 411. 
for superiors to be more loved than feared but admitted both qualities to be useful. ${ }^{23}$ Novices were to be chastised "with love and the instilling of fear" upon their third offense. ${ }^{24}$ Dismissal from the Society was to be used as an example so that those who defied authority "may fear the same thing." ${ }^{25}$ The Constitutions barred the Society's own members from disciplining unruly students but called for a non-Jesuit corrector who would use "some method of administering punishment" to keep troublemakers "in fear."26 Ignatius thus expected fear to motivate order within the Society, though always within strict limits and moderated by love.

The question of how these boundaries applied to the enslaved was a perpetual source of tension between Jesuit administrators and their plantation overseers. A stream of denunciations from provincials, visitors, and superiors general implies a pattern of overseers resorting to cruelty and officials attempting to reign them in. In 1687, the Argentine provincial José de la Barreda (dates unknown) barred overseers from dripping hot candle wax on enslaved people's skin or hanging slaves off the ground by their wrists (he decided the latter practice was acceptable as long as their feet remained on the ground). De la Barreda also specified the maximum number of lashes (twenty-five for small offenses, seventy for serious ones) and the type of whip to be used (it could not be of knotted leather that drew blood after a few strokes). ${ }^{27}$ Two decades later, Jesuit Superior General Michelangelo Tamburini (1648-1730, in office 170630) received word of Indians on the Argentine haciendas being permanently maimed from severe whippings and confinement without food. He ordered the perpetrators expelled from the Society. ${ }^{28}$ Irish Jesuit Peter Kenney (17791841), visitor to Maryland in 1820 , issued a scathing report on the treatment of the enslaved and removed the manager at St. Inigoes plantation who was overly fond of punishment. His instructions banned the whipping of pregnant women but allowed priests to whip men. ${ }^{29}$ In the Iberian empires, this dialectic between administrators and overseers led to printed instruction manuals

23 Constitutions, 334.

24 Constitutions, 188.

25 Constitutions, 102.

26 Constitutions, 166 and 188.

27 Nicholas P. Cushner, Jesuit Ranches and the Agrarian Development of Colonial Argentina, 1650-1767 (Albany: State University of New York Press, 1983), 106.

28 Cushner, Jesuit Ranches, 111.

29 Thomas Murphy, Jesuit Slaveholding in Maryland, 1717-1838, Studies in African American History and Culture (New York: Routledge, 2001), 117; Robert Emmett Curran, "'Splendid Poverty': Jesuit Slaveholding in Maryland, 1805-1838," in Catholics in the Old South: Essays on Church and Culture, ed. Jon L. Wakelyn and Randall M. Miller (Macon, GA: Mercer University Press, 1999), 34-38. 
for the Society's plantation managers ${ }^{30}$ but no comparable materials appeared for the French colonies..$^{31}$ La Marche's report was another site where this tension became visible.

Lavalette entered this world of fear and cruelty when he arrived on Martinique in the 1740s. Appointed procurator (1748) then superior of the mission (1753), Lavalette embarked on an ambitious expansion campaign to augment the mission's revenues. His early projects included building rental houses in St. Pierre and renovating the St. Pierre plantation. In 1748, he purchased a plantation and eighteen enslaved people at Grand Bay, on the neighboring island of Dominica. Though there is evidence that Lavalette only brought a fraction of the Grand Bay plantation into cultivation, he wrote of it producing coffee and foodstuffs under the supervision of a brother coadjutor, Nicholas Le Vasseur (b.17oo). ${ }^{32}$ Archeological excavations at Grand Bay have revealed a church, a residence, and a factory building. ${ }^{33}$ To work this investment, Lavalette acquired another four hundred people, a move which would have tripled the mission's total workforce. ${ }^{34}$ At Lavalette's direction, Le Vasseur also signed a sale purchasing five enslaved people from a neighboring free black woman named Gertrude for thirty-two hundred livres tournois. ${ }^{35}$

Where other missionaries in the islands wrote of enslaved Africans as potential converts who needed to be educated and Christianized, Lavalette wrote

30 For examples of these texts, see Pablo Macera, Instrucciones para el manejo de las haciendas jesuitas del Perú (ss. XVII-XVIII), Nueva Corónica 2 (Lima: Universidad Nacional Mayor de San Marcos, 1966) and François Chevalier. Instrucciones a los hermanos jesuitas administradores de haciendas (Mexico City: Universidad Nacional Autónoma de México, 1950).

$31 \quad$ Arnold J. Bauer, "Christian Servitude: Slave Management in Colonial Spanish America," in Agrarian Society in History: Essays in Honour of Magnus Mörner, ed. Magnus Mörner, Mats Lundahl, and Thommy Svensson (London: Routledge, 1990), 89-107, here 100.

32 Another priest, Fr. Lancastre, also oversaw the early years of the plantation. Antoine Lavalette, "Mémoire Justificatif," ARSI, Gall. 115, fols. $101^{\mathrm{v}}-102^{\mathrm{r}}$, henceforth "Mémoire Justificatif." Stephan Lenik, "Frontier Landscapes, Missions, and Power: A French Jesuit Plantation and Church at Grand Bay, Dominica (1747-1763)" (PhD diss., Syracuse University, 2010), 152 and 299 .

33 Lenik, "Frontier Landscapes," 187-207.

34 Lavalette, "Mémoire Justificatif," fols. $100^{\mathrm{r}}-101^{\mathrm{v}}$. The Jesuits' enemies later claimed that he purchased these enslaved people from Barbados disguised as a flibustier. Lettres sur les opérations du P. Lavalette, 176o, 32-34.

35 Parlement du Paris, Ordre général et définitif de tous les Créanciers des Ci-devant Soi-disans Jésuites, tant en France que dans Les colonies... (Paris: Pierre-Guillaume Simon, 1772), 206-7. 
of them as investments. "A negro costs me 1,00o livres [...]," he explained in a post-scandal apologia,

I will pay 75 livres [...] in interest; I put down another [...] 170 livres for their meat and clothes and their part in the costs of the plantation, which is 250 livres [...], a sum which I must recoup from the product of their work. And what is that profit? [...] 500 pounds of coffee, at 18 sols which makes $45^{\circ}$ livres [...]. Thus there remains 200 livres in profit. The negro must thus pay for themselves in 5 years and furnish their part of the plantation's expenses. ${ }^{36}$

In one project, a 1753 state contract for wood, he intentionally underbid the contract and sold enslaved people to make up the difference. With the down payment, Lavalette rented enslaved woodcutters from a neighbor and purchased enslaved fieldworkers at a cheap price. Both were put to work hewing the wood in Dominica's forests. Afterwards, Lavalette used the fieldworkers' experience as woodcutters to sell them for a higher price, thus recouping the losses from the underbid contract. ${ }^{37}$

Enslaved people also formed the base of the currency exchange network, which would ultimately lead to his downfall. From $175^{1}$ onward, colonists returning to Europe could deposit funds with Lavalette in exchange for commercial paper which could be redeemed from the professed house in Paris or with his merchant partners in Marseille. Where most merchants discounted bills bound for Europe by one-third to reflect a currency differential between France and the colonies, Lavalette promised to transfer the money at par, making his services an enticing prospect. ${ }^{38}$ Not only would Lavalette have been

36 Lavalette gives the amounts in both French livres and Roman écus. "J'avais donc dit: Une nègre me coutait 1000\# ou 200 écus- Je payerai $75^{\#}$ ou 15 écus d'intérêt; je mettais en autre 35 écus ou 170\# pour le viande et ses habits et sa cout part du frais de l'habitation, ce qui faisait 50 écus ou $250 \#$, somme que je devais d'abord trouver dans le produit de son travail, quel était-il? 500 livres de café, à 18 sols, qui faisait 450\# ou 9o écus- il ne restait de donc de bon 40 écus. Le nègre devait donc se payer dans 5 ans et fournier sa coute part des frais de l'habitation," Lavalette, "Mémoire Justificatif," fols. $102^{\mathrm{r}-\mathrm{v}}$. All translations from French and Latin are my own unless otherwise indicated.

37 Lavalette lays out his woodcutting plan in the "Mémoire Justificatif," fols. $102^{\mathrm{r}}-104^{\mathrm{v}}$.

$3^{8}$ Lavalette's agents in France claimed that he achieved this result through a complicated system of arbitrage between the prices of sugar and gold in Martinique and Marseille. It does not appear, however, that this system worked in practice. Most of his clients never received their money in France. For the description of the arbitrage system, see Charlemagne Lalourcé and Jean Lioncy, Mémoire à consulter et consultation pour Jean Lioncy, créancier, et syndic de la masse de la maison de commerce, établie à Marseille sous le nom de Lioncy frères, et Gouffre, contre le corps et société des P. P. Jésuites (Paris: P. Alex. Le Prieur, 1761), 3-9. 
paid in kind with slave-produced cash crops, at least one client paid with slaves. A list of Lavalette's creditors enumerated a bill of exchange for "the price of negros, negresses, \& and effects" sold to Lavalette by one Hericher Montigny in November of $1758 .{ }^{39}$

When Lavalette acquired Montigny's "negros and negresses" the mission's situation had degraded. The growth of the late 1740 s and early 1750 os ended with the outbreak of the Seven Years' War in 1756. While the war increased demand for Lavalette's financial services, the privateering war brought transatlantic shipping to a halt, leaving Lavalette's agents in France without the funds to pay off his client's bills of exchange and leading to the scandal that bears his name. The mission's enslaved workers also suffered. Hurricanes hit Martinique in 1751, 1756, and 1758. A 1755 epidemic killed off many of Grand Bay's enslaved men and women. Le Vasseur estimated the disease cost the mission 120,000 livres. ${ }^{40}$ The privateering war also created food shortages such that in 1758 and 1759 Martinique survived from the pickings of French privateers. ${ }^{41}$ Although demographic data for the Jesuit plantations is lacking, nutritional deficiency may have led to a rise in mortality. By 1758, Lavalette and the enslaved Africans on whom he relied were in crisis. In 1758, according to La Marche, Lavalette began killing slaves.

\section{$3 \quad$ Murder}

Jean-François de la Marche was a stranger to the Caribbean. Sixty-one-years old when he was appointed visitor to investigate Lavalette's financial affairs, he had left France only once, to teach grammar in Quebec. For the past thirty years, he had lived in the Society's professed house in Nantes, an Atlantic port city and the center of France's slave trade. There, he would have seen enslaved Africans in the streets and may have heard stories from Caribbean missionaries who passed through the town. But he reached the West Indies in the autumn of 1761 as an outsider unfamiliar with the workings of plantation slavery. ${ }^{42}$

Stopped by privateers during the Atlantic voyage, La March traveled down the Antilles in the wake of the British conquests, collecting evidence and sending status updates to Rome along the way. Dominica was his last stop before meeting Lavalette in person on Martinique. At Grand Bay, he met Le Vasseur, who

39 "Prix des nègres, négresses, \& effets." Parlement de Paris, Ordre général, 107.

40 Rochemonteix, Antoine Lavalette, 129.

41 Richard Pares, War and Trade in the West Indies, 1739-1763 (London: F. Cass, 1963), 384-85.

42 See La Marche's biography in ARSI, Gall. 121. 
showed him Lavalette's correspondence and answered his questions. During several days of investigations, La Marche discovered evidence that atrocities had taken place there under Lavalette's orders. "Without doubt in the year 1758," La Marche wrote, "[Lavalette] sentenced to torture many captives."43

His list of the victims began with Renata, whom La Marche described as a married woman from the Saint-Pierre plantation. Lavalette had her transferred to Dominica where she "met death in torture." 44 Le Vasseur argued to stop the "inhuman and barbarous experiment," but Lavalette ignored his pleas and brought in someone named L'Etang to conduct the tortures instead. ${ }^{45}$ Renata's death must not have produced the results Lavalette wanted, since he wrote to Le Vasseur five days afterwards that "the torment and DEATH of another one will strongly render and induce a full confession." ${ }^{46}$ A month later an enslaved widow, Catherine, "equally in torment breathed out the soul."47 La Marche also blamed Lavalette for the death of two runaway men, Martin and Condo, who died while in chains. ${ }^{48}$ After their deaths, Lavalette had the bodies of his victims either thrown into the sea or buried deep in Dominica's mountainous interior. "The privation of burial," he wrote to Le Vasseur, "will inject strong terror." ${ }^{99}$ Their souls would not be allowed to rest in peace.

La Marche was vague about what form the torture took but he mentioned two distinct devices. "I saw myself that awful deadly instrument of torture," he wrote, "and I ordered it as soon as possible to be handed over to the flames \& burned from the inside, there remains only a vestigial stump of it. I saw also the machine which it is not lawful for private men to keep [...] the name [...] of such kind of machine in France is called Sep. and it is said to have first been invented in Spain." ${ }^{50}$ French courts of the period used two forms of torture in

43 "Nimirum anno 1758, jussit tormentis addici captivos plures inter quos, omissis aliorum nominibus, appellandos esse duo quatuor quia exturbati sunt ex numero vivorum." La Marche, "Report."

44 "Mortem abierat in tormentis." La Marche, "Report."

45 "Ab inhumano ac barbaro ejusmodi experimento." La Marche, "Report."

46 "Tormentum et MORS aliorum cautiorem illum fortasse reddet atque ad plenam adducet confessionem." La Marche, "Report."

47 "Pariter in tormentis animam exhalavit." La Marche, "Report."

48 "Reliqui duo, Martinus scilicet \& Condo Lucis usuram amisere, non quidem dum torquerentur, sed aliquanto post in vinculis, prior die 11 Mensis junii 1758, posterior autem die 11. Mensis Martii 1759." La Marche, "Report."

49 "Sepultae rae privatio terrorem forte injiciet." La Marche, "Report."

50 "Vidi ego ipse dira feralis instrumenta supplicii, et jussi ea quam primum flammis tradi et penitis comburi, ne quod remaneret vestigium phala vidi ac machineae quam a privatis hominibus asservari non licet, eam ab iisdem eam adhiberi non liceat ad extorquendam privata authoritate criminis cujus libet confessionem. Nomen autem ejusmodi machinae gallica dicitur Sep. et aiunt excogitatam primum fuisse ab Hispanis." La Marche, "Report." 
common with the Spanish Inquisition. One was the estrapade or strappado (garrucha in Spanish), in which the victim was yanked up and down by a rope tied to his wrists and run through a pulley. The sudden deceleration as the rope jerked to a stop would dislocate bones. The other was the question d'eau (toca in Spanish), in which large quantities of water were forcibly poured down the victim's throat. ${ }^{51}$ Both technologies extracted confessions without causing permanent damage. Since Lavalette does not appear to have cared about bodily damage and intended to induce maximum fear among the enslaved, his victims may have been subjected to the wheel, a form of public execution in use in Europe and the colonies. The victim's arm and leg bones were first broken by running a wagon wheel over them, then their limp limbs would be intertwined between the spokes. The victim would be left to die on display. ${ }^{52}$ Both the estrapade and the wheel had wooden infrastructure of the type described by La Marche.

La Marche explained that Lavalette enacted these tortures because many of the mission's enslaved men and women had died; some, it was rumored, at the hands of sorcerers. "Always assume that there are veneficos [sorcerers/poisoners ${ }^{53}$ on the plantation," Lavalette wrote to Le Vasseur in a letter quoted by La Marche. ${ }^{54}$ While the report does not go into detail about these deaths or the figures who caused them (La Marche was more interested in Lavalette's culpability than the motivations of the enslaved) it does imply the presence of enslaved healers on the Grand Bay plantation who may have been trying to end the wave of mortality. Lavalette may have seen these healers as threats to his spiritual authority and the deaths as their attempts to cripple the plantation.

African healers, whose practices crossed the modern divide between the medical and spiritual realms, were a necessary danger for planters. Their tactics ranged from doling out bundles of charms to assuaging spiritual forces with animal sacrifices to concocting herbal remedies. The majority of healers plied their skills among the enslaved although the lack of trained European

51 Lisa Silverman, Tortured Subjects: Pain, Truth, and the Body in Early Modern France (Chicago: University of Chicago Press, 2001), 94-98; Henry Kamen, The Spanish Inquisition: A Historical Revision (New Haven, CT: Yale University Press, 1997), 188-94.

52 Richard B. Merback, The Thief, the Cross and the Wheel (Chicago: University of Chicago Press, 1998), 158-61.

53 For a parsing of "venefico" and the French derivation "vénéfice," see Chelsea L. Berry, "Poisoned Relations: Medicine, Sorcery, and Poison Trials in the Contested Atlantic, 16801850" (PhD diss., Georgetown University, 2019), 45.

54 "Semper subdubita veram esse veneficos in praedio nostro." This is one of several report letters from Lavalette to Le Vasseur that La Marche quotes in the report. 
doctors in the Americas drove slave owners to seek African cures as well..$^{55}$ French missionaries worked symbiotically with these healing practices while trying to divert them into channels acceptable to the Catholic Church. A 1763 inventory of the Jesuits' Mont Louis plantation in Guiana listed an infirmière (healer) among its enslaved population. ${ }^{56}$ Lavalette himself enlisted the aid of an enslaved woman to cure a sickness in $1755 .{ }^{57}$ Jean Mongin, a Jesuit priest on Saint Christophe who conducted a survey of twenty-six enslaved healers in the 168os, drew a line between those who "only applied certain herbs and natural remedies" and those who "made it their business to heal with actual magic spells." He deemed the former practices acceptable while the latter were to be stopped through increased exposure to the sacraments. ${ }^{58}$ Missionaries could thus be opportunistic in their approach to African medicine, rejecting its spiritual practices while taking advantage of its healing knowledge. Only practices deemed to be outside church-approved channels invited eradication.

Despite this symbiosis, planters in the French Caribbean tended to conflate African healing practices with poison or sorcery as threats to the plantation system. Mongin claimed to know several enslaved African healers who were guilty of poison. His recommended punishment could have come from Lavalette's pen: "what really needs to be done, to provide an example," he insisted, "is to execute one of them." Unlike Lavalette, however, he settled for barring poisoners from the sacraments. ${ }^{59}$ As Chelsea Berry has noted, the number of poison cases on Martinique rose steadily during the early eighteenth century to a peak in the 175 os as part of a wave of poison accusations sweeping the circum-Caribbean. To deal with this perceived threat from below, state officials instituted special tribunals for poisoning cases and mandated autopsies for suspected

55 See James H. Sweet, Domingos Álvares, African Healing, and the Intellectual History of the Atlantic World (Chapel Hill: University of North Carolina Press, 2011). See also Karol K. Weaver, Medical Revolutionaries: The Enslaved Healers of Eighteenth-Century Saint Domingue (Urbana: University of Illinois Press, 2006).

56 Le Roux, Auger, and Cazelles, Loyola, 126-27.

57 Lavalette to Ricci. Sept. 1, 1759, ARSI, Gall. 114 II, fols. $1^{\mathrm{r}}-2^{\mathrm{v}}$.

58 "Ne de certaines herbes et remèdes naturels [...] qui se mêlent de guérir avec de véritables sortilèges." Marcel Chatillon and Jean Mongin, "Lettres du R.P. Mongin: Lévangélisation des esclaves au XVIIe siècle," Bulletin de la Société d'histoire de La Guadeloupe 61-62, $3^{\text {rd }}$ $4^{\text {th }}$ trimesters (1984): 115, https://doi.org/10.7202/1043829ar; Jean Mongin, "Letter from Fr. Jean Mongin, Missionary in America, to a Person of Quality from Languedoc, Written on the Island of Saint Christopher (May 1682)," "No Less an Object of Our Zeal," French Jesuit Letters on Slavery, https://jesuitlettersonslavery.wordpress.com/letter-from-fr-jean-monginmissionary-in-america-to-a-person-of-quality-from-languedoc-written-on-the-island-ofsaint-christopher-may-1682/ (accessed June 2, 2020).

59 "Il serait bien nécessaire, pour l'example qu'on en punît quelqu'un du dernier supplice," "Letter from Fr. Jean Mongin." 
victims. Martinican officials heard ten such cases in 1755 alone, more than the number reported in the much larger colony of Saint Domingue. ${ }^{60}$

La Marche's glimpse of a spate of deaths sparking fears of a poison/sorcery ring bear remarkable similarity to the Makandal affair, a poisoning scare on Saint Domingue around the same time. In 1757 and 1758, large numbers of whites, blacks, and cattle died across the colony's northern plain. An enslaved man named Médor confessed that an organized poisoning ring was to blame, prompting twenty-one arrests. After nine months of tortures and inquisitions, the authorities arrested Makandal, a Congolese spiritual figure, as the ringleader. Makandal had aroused suspicions by distributing spiritually charged bundles of charms to his followers. Despite Makandal's bundles not being poison, colonial officials publicly burned him at the stake. Médor's confession aside, there is scant evidence that a poisoning ring even existed. Historians currently blame the deaths on spoiled grain brought by smugglers during the Seven Years' War. The suspects arrested during the outbreak claimed that they were offering spiritual protection and healing to the sick with no intention to kill them. ${ }^{61}$

The timing between the Makandal affair and Lavalette's string of tortures is suggestive. The arrests for poisoning on Saint-Domingue began in May 1757 and ended in March 1758, preceding and overlapping with Lavalette's killings. State authorities burned Makandal at the stake in January 1758. Renata became the first of Lavalette's victims two months later. ${ }^{62}$ Like Makandal, the enslaved men and women on the Jesuit plantation may have been using African healing practices to ward off sickness and malnutrition, signs Lavalette would have misread as sorcery or poison.

Lavalette understood the communal power of burial and the demoralizing effects of its deprivation. Vincent Brown has described the burial rituals among the enslaved of Jamaica as moments of community reinforcement where "the enslaved recovered a sense of their common humanity at funerals." Through singing and dancing, they renewed the family bonds and communal relationships forever being destroyed by the plantation system. Pallbearers carried the body around the village, stopping at doorways to collect debts and avenge wrongs. Such actions placated the deceased and allowed their spirit to depart

6o Chelsea L. Berry, "Poisoned Relations," 115-24; Trevor G. Burnard and John Garrigus, The Plantation Machine: Atlantic Capitalism in French Saint-Domingue and British Jamaica (Philadelphia: University of Pennsylvania Press, 2016), 108.

61 Burnard and Garrigus, Plantation Machine, 103-22.

62 Burnard and Garrigus, Plantation Machine, 103-22; Ghachem, "Prosecuting Torture." 
in peace rather than haunt the community. ${ }^{63}$ As Marissa Fuentes has noted, Barbados clamped down on funeral rituals for enslaved people convicted of crimes during the 1760 . Their bodies were to be buried at sea or thrown down wells, thus depriving enslaved Africans of the bodies' spiritual power. ${ }^{64}$

La Marche's European sensibilities were so shocked by the killings that he worried whether his report would be believed. "I know my story is truly unbelievable"; he wrote, "but all of the aforesaid things are faithful and true, known in public and private and furthermore now supported by records so that it is by no means possible to call them into doubt." ${ }^{65}$ To demonstrate the credibility of his findings, La Marche listed the enslaved victims' names and the dates of their executions, thus preserving the identities of Catherine, Renata, Martin, and Condo for posterity. He also quoted several excerpts from Lavalette's letters to Le Vasseur. Finally, La Marche summarized Articles 42 and 43 of the Code Noir forbidding planters from torturing their slaves, thus drawing a clear contrast between Lavalette's actions and the civil law. From this evidence, he concluded that Lavalette was guilty of voluntary homicide. The killings had been conducted in private, outside the legal authority of the French state. ${ }^{66}$ Such a sin was beyond his spiritual powers to heal. The Holy Office had not given him the power to absolve voluntary homicide.

With La Marche's report to Rome, all discussion of Catherine and Renata's deaths ended. His list of recommendations included better spiritual care for the enslaved but said nothing about the use of torture. Lavalette was never brought to royal or ecclesiastical justice for the killings. La Marche made no effort to prosecute Lavalette's violation of the Code Noir before Martinique's Superior Council. With the Jesuits' enemies trumpeting any rumor of Jesuit crimes, such a prosecution would have been against the Society's interests. Lavalette was punished internally, but not for torturing the mission's slaves. A consult headed by La Marche found Lavalette guilty of engaging in profane commerce, removed him from power, and ordered him returned to Europe. He was forbidden to administer the sacraments until the superior general ruled otherwise. The consult's judgement, written to absolve the Society from

63 It is unclear whether the Jesuits' enslaved community on Dominica followed similar rituals, given the missionary's Christianization efforts. Brown, Reaper's Garden, 66-74.

64 Fuentes, Dispossessed Lives, 117.

65 "Scio equidem narrare me incredibilia; sed praedictarum rerum fides ac veritas totae tantis et publicis, et privatis, et etiam num extantibus astruitur monumenta ut nullo modo vocari possit in dubium." La Marche, "Report."

66 "Acta autem fuisse harmonia a patr Ant. nulla judicis Legitimi authoritate publica, sed privata heriti tantum authoritate corto cutius constat." La Marche, "Report." 
liability for Lavalette's actions, made no mention of the dead slaves. ${ }^{67}$ Lavalette left the Society of his own volition, shortly afterwards. In Rome, Superior

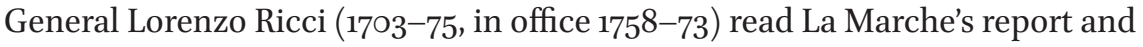
confirmed that Lavalette was guilty of cruelty and homicide. ${ }^{68} \mathrm{He}$ accepted Lavalette's departure from the Society and made no effort to pursue him further. During the expulsion, Lavalette's creditors sequestered and sold off the Martinique mission's properties, including their human property, in restitution for his debts. It is unknown what became of the enslaved men and women. ${ }^{69}$

At least one of the Society's historians, Camille de Rochemonteix (1834-1923), was complicit in covering up Lavalette's atrocity through his selective silences. In 1907, Rochemonteix published Le père Antoine Lavalette à la Martinique d'après beaucoup de documents inédits with the express purpose of clearing the Society of blame in Lavalette's financial activities. Rochemonteix's mastery of the archival sources made it the authoritative account of the "Lavalette affair" through the twentieth century. Rochemonteix quoted at length from La Marche's report, but ignored the deaths of the enslaved people. ${ }^{70}$ Only recently has Lavalette's cruelty come to light. D. G. Thompson, who wrote a detailed article on Lavalette's debts in 1996, read Ricci's commentary and wrote that Lavalette "committed [...] terrible acts which all but one of the Jesuit commentators [Ricci] passed over in silence. As a man of sometimes violent temper, he was rumored to have tortured slaves to death." ${ }^{11}$ La Marche's report shows these tortures were premeditated murders.

\section{Conclusion}

It would be easy to dismiss Lavalette's atrocities as the extreme actions of a wayward priest conducted without the Society's knowledge. Jesuit officials never permitted the killing of enslaved people on any of the Society's plantations, preferring instead to sell off people whom they perceived to be troublesome. Lavalette was already under investigation for wrongdoing and was soon

67 See ARSI, Gall. 114 I, fols. $77^{\text {r-v }}$.

68 By this point in 1762, the French parlements were in the process of expelling the Society. See Lorenzo Ricci, "Istoria dell'accaduto in Francia ai PP della Compagnia di Gesù," ARSI, Hist. Soc. 273 , fols. $87^{\mathrm{r}}-88^{\mathrm{v}}$. I thank D. G. Thompson for providing me with a French translation of this document.

69 Lenik, "Frontier Landscapes," 153; Rennard, Histoire religieuse, 249-52.

70 Rochemonteix quotes entire paragraphs from the same page as La Marche's description of torture. Rochemonteix, Antoine Lavalette, ${ }^{154-56}$ and $254-56$.

71 Thompson, "Lavalette Affair and the Jesuit Superiors," 215. 
to be removed from power. However, the accounts of cruelty on other Jesuit plantations and the sentiments expressed by other French Caribbean Jesuits point to Lavalette's killings as one episode in a long running tension between Society's religious mission and the realities of the plantation. For the visitor newly arrived from Europe, torturing enslaved men and women was behavior unbecoming of a Jesuit priest. For Lavalette, accustomed to the sovereignty of the planter class, it was a rational response to a perceived threat from below.

"The privation of burial will inject strong terror." The words stick with me. Lavalette's killings were meant to inspire fear. The tone of horror in La Marche's report signals that the enslaved weren't the only ones shocked by his actions. That a Jesuit priest could get away with murder should still shock us today. As the Society of Jesus struggles to reconcile with its slaveholding past, Lavalette's murders are a warning of further shocks that await. In past histories, like that of Rochemonteix, such gruesome events have been ignored, silently passed over in favor of more heroic tales. It is this author's hope that now they can be discussed openly in a spirit of reconciliation and remembrance. Perhaps now Martin, Catherine, Renata, and Condo will be able to rest in peace. 